\title{
Assistant Multi-Parametric Method to the selection in the Process of Incorporation of Hospital Equipment
}

\author{
By A. M. Marciano', L. S. Schneider², J. Pedroni² \\ ${ }^{1}$ Moinhos de Vento Hospital/ Clinical and Hospital Engineering, Porto Alegre, Brazil \\ ${ }^{2}$ Moinhos de Vento Hospital/ Hospital Engineering, Porto Alegre, Brazil
}

\begin{abstract}
This project aims to demonstrate a multi-parametric method of hospital technology comparison. The main goal was to develop a method to assist the clinical and hospital engineering team, in the process of acquisition and incorporation of medical-hospital equipment, to be used as a tool in the comparison stage of brand options and models of available equipment in the market. The method is composed by groups of criteria or characteristics that can be evaluate referring to the technologies to be compared. This method was applied to compare autoclaves and disinfecting machines that would be purchased to install in a Material Central and Sterilization in a hospital in the south of Brazil. As a result, it was obtained the classifications with the final scoring referring to each brand and model of technology. It also contributed significantly to assist the choice definition of the equipment, considering the hospital and technology profile, as well as the requirements and expectations of the multi-professional technical group of evaluators and users.
\end{abstract}

Keywords - Multi-parametric Method, Hospital Equipment Comparison, Selection Assistance, Incorporation Process.

Copyright (C) 2021. This is an open-access article distributed under the terms of the Creative Commons Attribution License (CC BY): Creative Commons - Attribution 4.0 International - CC BY 4.0. The use, distribution or reproduction in other forums is permitted, provided the original author(s) and the copyright owner(s) are credited and that the original publication in this journal is cited, in accordance with accepted academic practice. No use, distribution or reproduction is permitted which does not comply with these terms.

\section{INTRODUCTION}

Where technologies are evolving with great speed, new priorities in the medical device incorporation process are emerging. Medical equipment must correspond to local clinical needs, as well as be accurate and reliable in the environment for which they are used, in order to generate safety and effectiveness for health care. ${ }^{1}$ Medical device incorporation as defined by Wang "Is the entire process of absorbing technology into a health system or organization through planning, selection, and acquisition, with emphasis on its dependence on technology policies and continuous feedback from technology management."

The acquisition process of hospital equipment requires a defined criteria to make the comparison possible between different equipment from different brands and models and to the ensure ease of incorporation in the hospital for a specific application. A few items that must compose the technical specifications list of the equipment to be purchased, are the characteristics of use, functioning principle, nominal capacity, physical dimensions, indication mode and parameter record, outputs and inputs, accessories, construction characteristics, safety, etc. ${ }^{3}$

Most hospitals (75\%) do not have any decision-making tools such as multiple criteria decision analysis. Table 1 represent the categorization of different criteria used by hospitals to select a medical device by the degree of importance or the applied weight. ${ }^{4}$ 
TABLE 1. Categorization of Different Criteria used by Hospitals to Select a Medical Device by the Degrees of Importance

\begin{tabular}{|c|c|}
\hline $\begin{array}{l}\text { Degrees of } \\
\text { Importance }\end{array}$ & Criteria \\
\hline Essential & $\begin{array}{l}\text { - Technical characteristics } \\
\text { - Vendor evaluation } \\
\text { - Legal aspect } \\
\text { - Safety aspect }\end{array}$ \\
\hline Very important & $\begin{array}{l}\text { - Current use of technology } \\
\text { - Material resources / supplies } \\
\text { - Type of qualification / training required }\end{array}$ \\
\hline Important & $\begin{array}{l}\text { - Costs-effectiveness and economic benefits } \\
\text { - Clinical effectiveness } \\
\text { - Clinical efficiency }\end{array}$ \\
\hline Little important & $\begin{array}{l}\text { - Evidence of adverse events, occupational hazards } \\
\text { and other risks to users. } \\
\text { - Departmental modifications }\end{array}$ \\
\hline Irrelevant & $\begin{array}{l}\text { - Ethical analysis } \\
\text { - Acceptance of technology in institution } \\
\text { - Patient and social aspects }\end{array}$ \\
\hline
\end{tabular}

An alternative to comparison of hospital equipment is to use a matrix composed by the models of the equipment and its technical characteristics with the possibility of defining the weights of each characteristic and grade. After finding the results of each characteristic and multiplying the weight by of grade given by the specialists in the evaluation, it is possible to obtain the final scoring for each brand and model of the evaluated equipment. The characteristics suggested in this method are reliability, precision, repeatability, safety, maintainability, interchangeability, performance, and cost. ${ }^{5}$ Another options of characteristics that could be included in the comparison are the estimated price of parts, the existence of the part in national market, the stock list of the provider, the ease of importing parts, the proximity of the provider, stocking costs, reliability of the provider, and stoppage cost of the equipment by lack of parts. ${ }^{6}$

In the process of the comparison matrix development it was observed that a model should grade, weight, and categorize the features. This comparative matrix has three categories. The technical evaluation is composed of: precision, repeatability, maintainability, safety, performance, reliability and ergonomics. The clinical evaluation category includes the operation features, alarms, and display. And the third category, the financial evaluation accounts for the cost of the equipment, accessories, contract, and cost of the test instruments. ${ }^{7}$

In this line of categorization, there is also a spreadsheet that proposes additional categories that can be evaluated, them being: Safety (by mechanical and electric features), human engineering (design evaluation criteria, ease of maintenance, maintenance instructions, etc.), users experience (clinical engineering, doctors, nurses, and reports from other hospitals that have the referred equipment already evaluated, as a way of benchmarking) and other factors (such as standardization, familiarity). In this method, besides grouping criteria, scoring, and weighing, it is also suggests the weights of categories (0 to 1 ) and the grades for each criteria (0 to 10 ). ${ }^{8}$

Health care decisions are complex and involve confronting trade-offs between multiple, often conflicting, objectives. Using structured, explicit approaches to decisions involving multiple criteria can improve the quality of decision making. A set of techniques known under the collective heading, multiple criteria decision analysis (MCDA), are useful for this purpose. MCDA methods are widely used in other sectors, and recently there has been an increase in health care applications. ${ }^{9}$

The technology assessment domain corresponds to the choice and applying of multi-criteria methods in supporting the decision, such as: Analytic Hierarchy Process (AHP), Multi-Attribute Failure Mode Analysis (MAFMA), Elimination and Choice Translating Reality (ELECTRE) among others. ${ }^{10}$ Multi-criteria decision analysis (MCDA) concepts, models, and tools have been used increasingly in health technology assessment (HTA), with several studies pointing out practical and theoretical issues related to its use. ${ }^{11}$

The goal of this project was to develop a multi-parameter method to assist the process of acquisition and incorporation of hospital technologies which can be used as a tool in the comparison stage of brands and models of equipment available. Also, this project would contribute methodically and standardized a more assertive definition of the choice of equipment while considering the hospital profile, technologies evaluated, users, and applications. 


\section{METHODS}

\section{A. Development of the multi-parametric method of evaluation}

The method was developed from the bibliographical research, by reading the technical specifications provided in the technical commercial propositions through the notes from hospital and clinical engineering professionals and is demonstrated in flow-gram in Figure 1.

FIGURE 1. Project development flow-gram

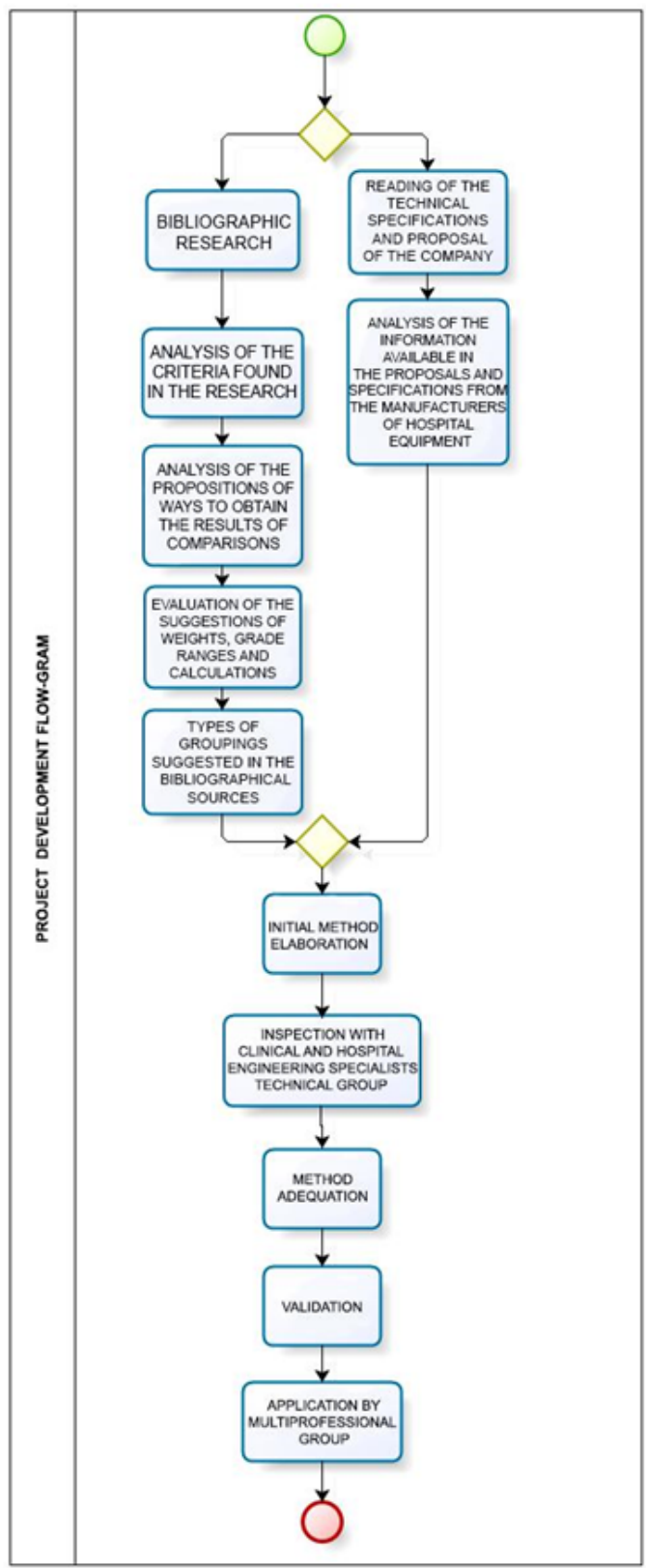

The stages demonstrated in Figure 1 were followed to develop the multi-parametric evaluation method of hospital equipment at the moment of acquisition to help determine the choice of model and equipment settings.

\section{B. Presentation of the criteria (or attributes) and groups (or categories)}

Examples of criteria and groups used to evaluate the technologies are demonstrated in Table 2.

TABLE 2. Evaluation Groupings and Criteria

\begin{tabular}{|c|c|}
\hline Group/Category & Examples of evaluated criteria \\
\hline Cost & $\begin{array}{c}\text { Installation, life cycle, parts, accessories, } \\
\text { inputs... }\end{array}$ \\
\hline Performance & Productivity related factors \\
\hline Provider & Structure, profile, team, after sales... \\
\hline Infrastructure & Infrastructure needs, utilities, electric, \\
water...
\end{tabular}

The information from Table 2 generated the following model, disposed in an Excel spreadsheet and presented in Table 3.

The proposed method, was used to compare the hospital equipment used in Material Central and Sterilization (CME) as support in the choice of autoclaves and washing disinfecting machines. A multi-professional group was created of specialists, composed by the areas of hospital engineering (clinical engineering, production and electric-mechanic) of CME (nursing and administration) and $\mathrm{CCIH}$ (nursing), to validate the weights and grades to each criterion, in agreement, considering the types of technology that would be evaluated. Meetings were organized to validate the scores. 


\section{Marciano, Schneider, Pedroni: Assistant Multi-Parametric Method to the selection in the Process of Incorporation of Hospital Equipment}

TABLE 3. Comparative Spreadsheet Configuration

\begin{tabular}{|l|l|l|l|l|l|l|}
\hline & $\begin{array}{l}\text { Criteria/ } \\
\text { attributes }\end{array}$ & $\begin{array}{l}\text { Group/ } \\
\text { category }\end{array}$ & Weight & Option 1 grade & Total grade of Option 1 & Total grade of Option 2,3,... \\
\hline 1 & & & & & & \\
\hline 2 & & & & & & \\
\hline $3 \ldots$ & & & & & & \\
\hline
\end{tabular}

The spreadsheet with the criteria was sent to the three providers that took part in competition. They only had access to the criterion list, not to the groups weights. Excel was used to generate the results with suggested calculations.

Table 4 shows some examples of the criteria and categories used to compare the washing disinfecting machines.

TABLE 4. Examples of Criteria and Evaluation Categories

\begin{tabular}{|c|c|}
\hline $\begin{array}{l}\text { What is the annual cost of non-contract preventive maintenance } \\
\text { and no MP kit in Porto Alegre? }\end{array}$ & Cost \\
\hline $\begin{array}{l}\text { What is the annual cost of non-contract preventivemaintenance } \\
\text { and MP kit in Porto Alegre? }\end{array}$ & Cost \\
\hline What is the cost of infrastructure adequacy? & Cost \\
\hline What is the cost of replacing the gate trim? & Cost \\
\hline What is the replacement cost of the resistors? & Cost \\
\hline What is the cost of the controller for the disinfecting machine? & Cost \\
\hline $\begin{array}{l}\text { What is the cost of the water reuse system for the disinfecting } \\
\text { machine? }\end{array}$ & Performance/Efficiency \\
\hline What is the water consumption per tray (in L)? & Performance/Efficiency \\
\hline What is the water consumption per complete cycle (in L)? & Performance/Efficiency \\
\hline What is the average time of the flash cycle including drying? & Performance/Efficiency \\
\hline What is the average time of the instrumental cycle including drying? & Performance/Efficiency \\
\hline What is the average cycle time for ventilator material including drying? & Performance/Efficiency \\
\hline What is the time for daily water heating when the machine is cold? & Performance/Efficiency \\
\hline What is the size of the inner chamber (height $\mathrm{x}$ width $\mathrm{x}$ depth)? & Performance/Efficiency \\
\hline What is the capacity of loading in number of DIN baskets? & Performance/Efficiency \\
\hline What is the load capacity in number of ISO baskets? & Provider \\
\hline $\begin{array}{l}\text { Does the company have any quality certification? (e.g. ISO 9001, } \\
\text { BPF, BPAD) }\end{array}$ & Provider \\
\hline $\begin{array}{l}\text { Does the company have its own or outsourced technical assistance } \\
\text { (representative) in POA? }\end{array}$ & Provider \\
\hline Does the warranty cover the door resistances and fittings? & Provider \\
\hline
\end{tabular}

\begin{tabular}{|c|c|}
\hline Do you provide operation manuals in Portuguese? & Provider \\
\hline Do you provide technical reference manuals? & Provider \\
\hline $\begin{array}{l}\text { Is there another differential related to the technical assistance } \\
\text { structure not addressed? If so, please comment }\end{array}$ & Provider \\
\hline $\begin{array}{l}\text { Will the engineers and technicians attending the HMV have an } \\
\text { NR- } 32 \text { or NR-10 training certificate? }\end{array}$ & Infrastructure \\
\hline What is the weight of the equipment? (net weight + charge) & Infrastructure \\
\hline What is the electric peak power? & Infrastructure \\
\hline What is the nominal electric power? & Infrastructure \\
\hline Is there a need for exhaustion? & Infrastructure \\
\hline Is there a need for a water treatment system? & Infrastructure \\
\hline Is there a need for an energy stabilization system? & Infrastructure \\
\hline Is there a need for a compressed air point? & Infrastructure \\
\hline $\begin{array}{l}\text { Does the passageway have the necessary floor dimensions/resis- } \\
\text { tance required for this equipment? }\end{array}$ & Maintenance \\
\hline $\begin{array}{l}\text { What is the maximum period for delivery of the pieces in Porto } \\
\text { Alegre? Inform in numbers of days }\end{array}$ & Maintenance \\
\hline \multicolumn{2}{|l|}{$\begin{array}{l}\text { What is the maximum time in hours for call after call on HMV } \\
\text { POA? (State whether there is difference with and without contract) }\end{array}$} \\
\hline $\begin{array}{l}\text { Does the manufacturer recommend preventive maintenance at what } \\
\text { intervals? }\end{array}$ & Maintenance \\
\hline What will be the technical assistance telephone service? & Maintenance \\
\hline $\begin{array}{l}\text { Does the company have stock for immediate supply of parts for the } \\
\text { maintenance of the products offered? Is there any part that you do } \\
\text { not keep in stock? (Please attach list) }\end{array}$ & Maintenance \\
\hline Allows remote access to services? What infrastructure is needed? & Maintenance \\
\hline In short, what preventive care will be required for this equipment? & Maintenance \\
\hline What are the types of maintenance contracts available? & Maintenance \\
\hline Can the equipment be connected to a material traceability system? & Operational/Usability \\
\hline Is the control display colourful? & Operational/Usability \\
\hline Does it have a printer / registration system? & Operational/Usability \\
\hline Does it send data for external printing? & Operational/Usability \\
\hline How is the door locking system? & Operational/Usability \\
\hline How are notifications and alerts displayed /viewed? & Operational/Usability \\
\hline
\end{tabular}




\begin{tabular}{l|c}
\hline What notifications appear on the display and are easyto see? & Operational/Usability \\
\hline What is the layout of the command? & Operational/Usability \\
\hline What is the layout of the display? & Operational/Usability \\
\hline What is the construction material of the inner chamber? & Safety \\
\hline Is the control display touchscreen? & Safety \\
\hline Are the measuring instruments calibrated? & Safety \\
\hline $\begin{array}{l}\text { Does it have the option of two independent control systems (one for } \\
\text { control and one for recording) as well as temperature sensors? }\end{array}$ & Safety \\
\hline How is the door security system? & Safety \\
\hline What is the guarantee of the chamber? & Safety \\
\hline What is the construction material of the generator safety valve? & Safety \\
\hline What is the door type? & Safety \\
\hline What is the spray cover of the spray arms? & Technology \\
\hline $\begin{array}{l}\text { What is the thermal dissipation? (Wall thickness and insulation } \\
\text { type) }\end{array}$ & Technology \\
\hline What is the construction material of the control panel? & Technology \\
\hline What is the construction material of the water pump? & Technology \\
\hline What is the electrical resistance construction material? & Technology \\
\hline What is the printer type? & Technology \\
\hline
\end{tabular}

The criteria were listed according to the number of specifications and technical descriptions that these types of equipment present. This was done through the initial proposals received from both the suppliers and the technical knowledge of the multiprofessional team from the hospital (which listed which criteria would be important to evaluate for the technical comparison of these types of equipment). The information or data in Tables 4 and 5 were initially obtained by sending the complete spreadsheets (some criteria were exemplified in Table 4) to the representatives / suppliers of the three equipment brands that participated in the comparison. The spreadsheets were received, filled in, and returned us with the information or data of the equipment.

After receiving the answers from the suppliers, they were evaluated by the multiprofessional group from the hospital according to the information received. These scores were equivalent to the levels of information provided by the manufacturers for each criterion (according to the consensus of this multiprofessional group).

\section{Weighing Coefficients}

The goal of the replacement of sterilization and thermodynamic equipment was to optimize flow, increase productivity, and thus qualify the service of Material and Sterilization Center, due to the demand in elevation and restricted physical area. For this, the multiprofessional group defined that the criteria / category of performance, and consequently technological characteristics / category (which allows increased productivity with decreasing process times, for example), as well as usability criteria / category (to facilitate the use, avoiding unavailability of the equipment due to doubts of use, difficulty of use and even misuse, were avoided). It was also defined that the post-sale / technical assistance category would have relevance (so that preventive maintenance and corrective maintenance routines were the most assertive and performed by a technical team capable of reducing downtime). We use AHP method to validate the consistency of the weights uses for each criterion.

\section{How to transform qualitative criteria to quantitative criteria.}

The multidisciplinary group defined analogy to transform criteria with qualitative to quantitative answers. For example, score from 0 to 5 , where 0 (equals not shown, non-existent). Score 1 (equals little, or bad, weak, ... up to 5 (equals a lot, good, strong, ...)

\section{RESULTS}

With the scores inserted a spreadsheet summarizing the final results was generated (Table 5).

The weight for the cost-related criteria group was $15 \%$. And as explained earlier, the initial goal was to increase productivity, and from this, given relevance to the criteria and groups, that would impact on productivity. The groups with the highest weights (with 15\%) were the cost criteria; Performance / Efficiency; Maintenance; Operation / Usability and Technical / Technology. It was also observed that the acquisition and lifecycle prices were similar, varying in a small range, between the three options of models and brands. Thus, incorporation and lifecycle costs would not have a major impact on the 
TABLE 5. Final Results of Option Comparison By Category

\begin{tabular}{|c|c|c|c|}
\hline & $\begin{array}{c}\text { Option } \\
1\end{array}$ & $\begin{array}{c}\text { Option } \\
2\end{array}$ & $\begin{array}{c}\text { Option } \\
3\end{array}$ \\
\hline $\begin{array}{c}\text { Cost Characteristics } \\
\text { (installation, life cycle, etc.) }\end{array}$ & 5,8 & 4,7 & 5,0 \\
\hline $\begin{array}{c}\text { Performance/Efficiency } \\
\text { Characteristics (productivity } \\
\text { related factors...) }\end{array}$ & 16,2 & 11,9 & 12,2 \\
\hline $\begin{array}{c}\text { Provider Characteristics } \\
\text { (structure, profile, team, after } \\
\text { sales...) }\end{array}$ & 8,9 & 8,4 & 9,6 \\
\hline $\begin{array}{l}\text { Infrastructure Characteristics } \\
\text { (structure needs, utilities, } \\
\text { electric, water...) }\end{array}$ & 6,0 & 6,5 & 4,1 \\
\hline $\begin{array}{l}\text { Maintenance Characteristics } \\
\text { (access, MTBF, Tx., failures, } \\
\text { stock parts...) }\end{array}$ & 4,7 & 4,4 & 5,1 \\
\hline $\begin{array}{l}\text { Operational Characteristics } \\
\text { (operation, functions, access, } \\
\text { facility, audiovisual indicators...) }\end{array}$ & 7,5 & 6,4 & 6,6 \\
\hline $\begin{array}{l}\text { Safety Characteristics (applied } \\
\text { technology, redundancies, } \\
\text { criteria, standards...) }\end{array}$ & 8,4 & 7,1 & 6,5 \\
\hline $\begin{array}{c}\text { Technical Characteristics } \\
\text { (constructive material, } \\
\text { applied technology, evolution, } \\
\text { component types...) }\end{array}$ & 16,1 & 14,6 & 18,9 \\
\hline Total & 73,5 & 63,8 & 67,9 \\
\hline
\end{tabular}

organization, if one or the other brand (among those compared) was chosen.

After generating the results an opinion was issued to the Purchases/Supplies sector of the hospital who performed the final scores for each brand/model of participating equipment. The acquisitions were made considering the best scores resulting from this method.

The deal was closed in the third trimester of 2016. The equipment arrived in the first trimester of 2017 and the installing was finalized in May of 2017. The machines are in initial process of use after going through installation, validation, performance, calibration, and operational training of the users and technical team. The technical trainings are scheduled for June/July of 2017.

\section{DISCUSSION}

Not only was the method model creation and definition laborious, so too was assigning the criteria (which were very extensive) and receiving the information from the providers/representatives. The companies, in general, don't know all their products' information. All companies needed to request information from their respective industries. These factors took a long time and delayed the comparison process.

It also required a lot of attention, time, and dedication to include the definition of weight average and scores to the criteria. Depending on the weight averages and scores, scales the differences in final scores became very tenuous. It was also necessary to define qualitative scales to support the quantitative scales. However, criteria don't always have data (quantitative) and there are criteria that are qualitative. Therefore, it is necessary to transform them into quantitative data. In some cases it was noticed that some characteristics interface/relate each other with others or that can be associated with more than one group/category.

Table 6 demonstrates the quantity of criteria defined, by group/category to be evaluated in the process of comparison.

TABLE 6. Criteria Quantity Defined by Category

\begin{tabular}{|c|c|c|}
\hline Group/Category & $\begin{array}{c}\text { Criteria Quantity } \\
\text { to Autoclave }\end{array}$ & $\begin{array}{c}\text { Criteria Quantity } \\
\text { to disinfecting } \\
\text { washing machine }\end{array}$ \\
\hline Cost & 22 & 22 \\
\hline Performance & 21 & 27 \\
\hline Provider & 24 & 25 \\
\hline Structure & 18 & 19 \\
\hline Maintenance & 11 & 9 \\
\hline Operation/ & 19 & 18 \\
\hline usability & 14 & 14 \\
\hline Safety & 29 & 32 \\
\hline Technology & 158 & 164 \\
\hline Total & & \\
\hline
\end{tabular}


The impacts of the technology sterilization substitutions, washing, and disinfection, will be measured concerning performance, productivity, maintainability, costs and other pre-evaluated criteria and can be certified in practice. Other comparative-method developments, including criteria inspection, groupings, weights, calculations, can be done. Additionally, the influence analysis on the types of technologies to be compared, in criteria and weights that work as a base to the comparison.

To make validations and adjustments possible you must have adhesion according to the technology to be compared. For example, this method was applied in other acquisition processes, as an assistant to the comparison of medical-hospital equipment. It was applied by both the hospital engineering team, to evaluate other technologies like air central and medicinal vacuum, and by the clinical engineering team, evaluating the multi-parametric monitor options and in other cases in which the results can be demonstrated in further projects.

\section{CONCLUSION}

The acquisition process of hospital equipment requires defined criteria to make comparison possible between different brands and models, and to point to the selection and consequent definition of which item will be more fit to incorporate in a certain hospital in a certain application.

This project proposed the development of a multicriterion method to support the acquisition process and incorporation of hospital technologies, to be used as a tool in the comparison stage of brand options and equipment models available in the market.

The project contributed significantly in the assistance of more assertive definitions of the steam autoclave and disinfecting washing machine, while considering the hospital profile, requirements, and expectations from the multi-professional technical group of evaluators and users. It is believed that methods like this must be developed and replicated according to the technology profiles of hospitals as well as their needs and acquisition goals.

\section{CONFLICT OF INTEREST}

The author declares not having conflict of interest.

\section{REFERENCES}

1. Margotti A, Santos F, and Garcia R. Decision Making Process to Incorporate Medical Equipment in hospital: Clinical Engineering Perception. in World Congress on Medical Physics and Biomedical Engineering, China: World Congress on Medical Physics and Biomedical Engineering May 26-31, 2012.

2. Wang B. Strategic Health Technology Incorporation (1st ed.). Connecticut: Morgan and Claypool; 2009.

3. Calil SJ. Fatores para a Aquisição de Equipamentos Médico-Hospitalares. Anais XVII Congresso Brasileiro de Engenharia Biomédica, Florianópolis, Brasil, p.3845.11-13 Setembro, 2000.

4. European Scientific Journal. February 2018 edition. Vol. 14. №. 6. ISSN: 1857 - 788 (Print e - ISSN 1857 $-743 .<\mathrm{AU}$ : Is this reference for the whole issue? If not, please add author and title>

5. Bronzino JD. Management of medical technology: primer for clinical engineers. Stoneham: ButterworthHeinemann; 1992.

6. Müller Jr., EL, Pedroso JCL. Aquisição de Equipamentos Médicos In: S.J. Calil; E.T. Gomide (Orgs.), Equipamento Médico-Hospitalares e o Gerenciamento da Manutenção: Capacitação a distância/Ministério da Saúde, Secretaria de Gestão de Investimentos em Saúde, Projeto REFORSUS - Brasília, DF: Ministério da Saúde. 2002; 153-180, 720.

7. Vergara Galeano JC. Procedimentos de Aquisição de Equipamentos Médico- Assistenciais: uma Ferramenta Computadorizada de Apoio. Dissertação (Mestrado em Engenharia Elétrica) - Programa de Pós Graduação em Engenharia Elétrica da Universidade Federal de Santa Catarina (UFSC), Florianópolis: 1999; 166.

8. Stiefel R, Riskalla E. The elements of a complete product evaluation. Biomed Instrument Technol 1995;29(6):482-88.

9. Thokala P, Devlin N, Marsh K, et al Multiple criteria decision analysis for health care decision making - an introduction: Report 1 of the ISPOR MCDA Emerging Good Practices Task Force. Value Health 2016;19:1-13.

10.Santos FA and Garcia R. Decision process model to the health technology incorporation. Conf Proc IEEE 
Eng Med Biol Soc. 2010;2010:414-7. doi: 10.1109/ IEMBS.2010.5627344.

11.Oliviera MD, Mataloto I, Kanavos P. Multi-criteria decision analysis for health technology assessment: addressing methodological challenges to improve the state of the art. Eur J Health Econom 2019;20:891-918. https:// doi.org/10.1007/s10198-019-01052-3 